\title{
SPEED TRAPS AND THE RigHT OF SILENCE
}

\author{
DENNIS KURZON \\ kurzon@research.haifa.ac.il \\ Department of English, University of Haifa, Israel
}

\begin{abstract}
In two English cases which reached the European Court of Human Rights in the mid2000s, it was argued that the statutory requirement on the part of a motorist who has been caught speeding to give the police information concerning the identity of the driver of the car at the time of the offence is a violation of the right of silence by which a person should not be put into a position that $\mathrm{s} / \mathrm{he}$ incriminates him/herself. The right of silence is one of the conventional interpretations of Article 6 of the European Convention on Human Rights.

As well as a study on the right of silence with regard to written texts, this paper also investigates the two cases in terms of icons and indices: a text may be indexical of a basic human right, and then may become an icon of that right. The European Court of Human Rights considers the particular section of the relevant statute as an icon of the "regulatory regime".
\end{abstract}

Key words: pragmatics, discourse, law, semiotics

\section{The Case Narrative}

\subsection{O'Halloran}

On April 7, 2000, a car owned by Gerard O'Halloran was photographed driving at $69 \mathrm{mph}$ on the M11 in England in a temporary 40mph zone. He was sent a letter from the local police, which included the following:

You have been named as the driver of the vehicle at the time of the alleged offence and have a legal obligation to comply with the provisions of the notice contained on page 2. I must warn you that if you fail to comply with this demand within 28 days you will commit an offence and be liable on conviction to a maximum penalty similar to that of the alleged offence itself - a fine of $£ 1,000$ and 3-6 penalty points.

Attached was the Notice of Intention to Prosecute (NIP), which he signed. The text ran:

You are recorded as the owner/keeper/driver or user for the above vehicle at the time of the alleged offence, and you are required to provide the full name and address of the driver at the time and location specified. Under section 172 of the Road Traffic Act you are required to provide the information specified within 28 days of receipt of this notice. Failure to supply this information may render you liable to prosecution. 
The penalty on conviction for failure to supply the information is similar to that for the offence itself, i.e. a fine and penalty points.

O'Halloran returned the NIP, signing it that he was the driver of the car at the time the photograph was taken. However, before the hearing at the magistrates' court in North Essex, where he was tried for driving in excess of the speed limit, he asked for the confession to be excluded on the grounds that sections 76 and 78 of the Police and Criminal Evidence Act of 1984 (henceforth, PACE 1984) read in conjunction with Article 6 of the European Human Rights (EHR) Convention both support the exclusion of such evidence (see below).

The court, relying on section 172 of the Road Traffic Act 1988 (henceforth "the 1988 Act") and on Brown v. Stott (see 2.2. below), ${ }^{1}$ which endorsed the legality of the 1988 Act, convicted O'Halloran, who was fined $£ 100$, ordered to pay $£ 150$ costs, and had his licence endorsed with six penalty points.

\subsection{Francis}

On June 12, 2001, an Alvis car owned by Mr. Idris Francis was photographed driving at the speed of $47 \mathrm{mph}$ in a 30mph zone in Guilford, Surrey in the UK. Unlike O'Halloran, Francis refused to sign the NIP. He wrote to the Surrey Police stating that he had the right to remain silent, invoking his privilege against self-incrimination. Even after being informed by the Surrey police that according to Brown v. Stott his right of silence was not being infringed, Francis still refused to provide the police with the information as to the identity of the driver of the car at the time of the speeding offence.

After a number of adjournments, and after Francis had applied to the EHR Court in Strasbourg, the magistrates' court dealing with his case imposed a fine upon him of $£ 750$ with $£ 250$ costs and 3 penalty points, which was, according to Francis, ${ }^{2}$ probably a punishment more severe than he would have received for the speeding offence alone.

Eventually, both cases were presented as a package to the EHR Court (O'Halloran and Francis v. The United Kingdom), claiming that the 1988 Act infringes a person's basic human right of silence when questioned by the police or by the court itself.

\section{The Legal Texts}

A number of legislative texts and cases were cited in the EHR court opinion of the two cases, issued on June 29, 2007. The texts I am relating to are Section 172 of the 1988 Act, section 78 of PACE 1984, Article 6 of the EHR Convention, as well as a number of precedents. At this juncture, we may say - if we may adopt Charles Peirce's terms (Peirce, CP 4.531) - that some of these sets of symbols, as these texts may be said to be, become indices (see 3.2. below).

\footnotetext{
${ }^{1}$ [2001] 2 WLR 817.

${ }^{2}$ From one of the websites of the Association of British Drivers (www.righttosilence.org.uk)
} 


\subsection{Legislative texts}

Subsection 2 of the 1988 Act states that when

the driver of a vehicle is alleged to be guilty of an offence to which this section applies-

(a) the person keeping the vehicle shall give such information as to the identity of the driver as he may be required to give by or on behalf of a chief officer of police...

and Subsection 3 provides that subject to

the following provisions, a person who fails to comply with a requirement under subsection (2) above shall be guilty of an offence.

The following subsection (4) lays down that

[a] person shall not be guilty of an offence by virtue of paragraph (a) of subsection

(2) above if he shows that he did not know and could not with reasonable diligence have ascertained who the driver of the vehicle was.

To prove the relevance of subsection (4), a person may have to claim that either his or her car has been stolen or s/he has no control over members of his or her family, who take the car without permission. Needless to say, neither of the two appellants invoked this subsection.

To fulfil subsection (2)(a) of the 1988 Act, all that a driver accused of a motoring offence has to do is to sign a statement that $\mathrm{s} / \mathrm{h}$ e was the driver of the vehicle which was photographed speeding. Such a statement would be accepted as evidence of that fact.

In their case before the EHR court, the two appellants - O'Halloran and Francis firstly claimed that section 78 of PACE 1984 would rule out such self-discriminatory evidence. This section states that in

any proceedings the court may refuse to allow evidence on which the prosecution proposes to rely to be given, if it appears to the court that, having regard to all the circumstances, including the circumstances in which the evidence was obtained, the admission of the evidence would have such an adverse effect on the fairness of the proceedings that the court ought not to admit it. (my emphasis)

The argument here could be worded in the following way: Since the source of the only piece of evidence that the driver at the time of the offence is the owner of the car, the court has to rely solely on this evidence to convict or not to convict. In other words, the owner would have either to incriminate him- or herself or to incriminate someone else, perhaps a member of the family.

Secondly, the appellants made use of Article 6 of the Human Rights Convention in claiming that section 172 of the 1988 Act is being violated by the British statute. The relevant article reads:

1. In the determination of his civil rights and obligations or of any criminal charge against him, everyone is entitled to a fair and public hearing within a reasonable time by an independent and impartial tribunal established by law...

2. Everyone charged with a criminal offence shall be presumed innocent until proved guilty according to law.

In cases previously argued before the EHR court, this article, especially section 2, has been interpreted as a guarantee of the right of silence. 


\subsection{Precedents}

I will relate to two previous cases, among others, claimed by both sides - by the appellants O'Halloran and Francis and by the UK government - to support their respective positions. In the first of the two, Brown v. Stott (see 1. above), a 2001 Scottish case, the defendant was initially arrested for shoplifting near a car which she was purported to be driving. After a breathalyzer test which found that she had an access of alcohol in her blood, it was alleged that she had been driving under the influence of alcohol. She signed the NIP stating that she was the driver of the car. This was the only piece of evidence the court had in order to prove that she had been driving a car with an amount of alcohol in her blood above the acceptable limit. In other words, if she had not incriminated herself, she could not have been convicted of drunken driving, but she could have been convicted of refusing to sign the NIP. The High Court of Justiciary allowed the defendant's appeal, since the prosecution could not rely as evidence on the admission which she had been compelled to make on the basis of section 172 of the 1988 Act.

The Procurator Fiscal (the public prosecutor in Scotland) appealed against the High Court of Justiciary's judgment to the Privy Council, which decided that the use of the NIP is not an infringement of the requirements of Article 6 of the Human Rights Convention. The leading judgment was given by Lord Bingham, in which he claimed, inter alia, that democratic societies have used a number of methods to deal with the high incidence of death and injury on the roads caused by the misuse of motor vehicles. One such method is

by subjecting the use of motor vehicles to a regime of regulation and making provision for enforcement by identifying, prosecuting and punishing offending drivers. ...

(1) Section 172 [of the 1988 Act] provides for the putting of a single, simple question. The answer cannot of itself incriminate the suspect, since it is not without more an offence to drive a car. (my emphasis)

Lord Bingham continued:

If, viewing this situation in the round, one asks whether section 172 represents a disproportionate legislative response to the problem of maintaining road safety, whether the balance between the interests of the community at large and the interests of the individual is struck in a manner unduly prejudicial to the individual, ... I would feel bound to give negative answers. (my emphasis)

Lord Bingham introduced into the argument the concept of "a regime of regulation" or "a regulatory regime". Modern states cannot function without sets of regulations that control what people can or cannot do, and control how people can do certain things. So, in order to drive a car, one must pass a driving test and pay a fee for the subsequent licence. In order to own and drive a car, one needs not only the driving licence, but also a car registration licence, car insurance and - in many countries - an annual test of roadworthiness. All this is part of the regulations a bureaucracy places on the individual citizen who is a car owner. Without these regulations, one cannot control what is going on on the roads, and reduce the accident rate, for example. It is the state that has to 
ensure that only competent drivers are allowed to drive vehicles, and that car insurance covers at least third-party injury, among other things. This is Bingham's "regulatory regime" as far as motor vehicles are concerned. So, signing a NIP after certain driving offences is considered part of this regulatory regime. In the same way that a driver hands over information concerning his or her identity while registering a car, $\mathrm{s} / \mathrm{he}$ has to sign an NIP when one is sent to him or her. In the balance between the rights of the individual and the need to run a modern state, it is the state that carries the day.

The second case, John Murray v. United Kingdom ${ }^{3}$ concerns a suspected member of the Irish Republican Army (IRA) in Belfast, who had allegedly illegally kidnapped and held prisoner a Mr L., who was an informer for the Royal Ulster Constabulary, the Northern Irish police force. On arrest Murray refused to give reasons for his being in the house where Mr. L was being held. He claimed the right of silence, as enunciated in the police warning:

You do not have to say anything unless you wish to do so but I must warn you that if you fail to mention any fact which you rely on in your defence in court, your failure to take this opportunity to mention it may be treated in court as supporting any relevant evidence against you. If you do wish to say anything, what you say may be given in evidence. $^{4}$

Later at the police station, Murray was questioned, and warned again, this time through use of the Criminal Evidence (Northern Ireland) Order 1988, section 3, which deals not only with a failure to relate to facts which may be used later as part of the defence, but also with possible interpretations of silence during subsequent proceedings. The relevant part of the section reads:

Circumstances in which inferences may be drawn from accused's failure to mention particular facts when questioned, charged, etc.

Where, in any proceedings against a person for an offence, evidence is given that the accused ... on being charged with the offence or officially informed that he might be prosecuted for it, failed to mention any such fact, being a fact which in the circumstances existing at the time the accused could reasonably have been expected to mention when so questioned, charged or informed, as the case may be, ...

the court or jury, in determining whether the accused is guilty of the offence charged, may

(i) draw such inferences from the failure as appear proper;

(ii) on the basis of such inferences treat the failure as, or as capable of amounting to, corroboration of any evidence given against the accused in relation to which the failure is material.

The court in Murray v. United Kingdom related to the accused's right of silence, but at the same time, it

deems it equally obvious that these immunities cannot and should not prevent that the accused's silence, in situations which clearly call for an explanation from him, be

\footnotetext{
${ }^{3}$ ECHR 1996, 41/1994/488/570

${ }^{4}$ This is the version used in Northern Ireland. For the genesis of the new police warning in England and Wales, see 3.2. below.
} 
taken into account in assessing the persuasiveness of the evidence adduced by the prosecution.

Wherever the line between these two extremes is to be drawn, it follows from this understanding of "the right to silence" that the question whether the right is absolute must be answered in the negative. (Par. 47)

Hence, courts generally interpret the right of silence as a right relative to the regulatory regime required to run a modern state (as laid out in Brown v. Stott), and relative to what would be a normal interpretation of silence in everyday conversation (as in John Murray v. United Kingdom).

\subsection{The submission of the parties}

The argument, therefore, between the British government and the two appellants in the case before the EHR Court was clearly divided between the interpretation of the right of silence as a relative right and its interpretation as an absolute right.

The Government maintained that both the privilege against self-incrimination and the right to remain silent were not absolute. These rights must be evaluated in the context of "other legitimate aims in the public interest". 5 s long as "the fair balance between the interests of the individual and the general interests of the community" (ibid.) is not being disturbed, it was submitted, governments may, in specific situations, "reverse the onus of proof of certain matters" (ibid.).

On the other hand, the two appellants argued that there are other means to achieve the same result without infringing basic human rights, of which the right of silence is one such right. Another method, acceptable in many countries, is "a statutory presumption of fact that the registered owner was the driver unless he or she provided evidence to the contrary". ${ }^{6}$ Certain presumptions are necessary in legal proceedings. Hence, holding that a regulatory regime is necessary for running a modern state does not mean that existing methods are necessary to maintain such a regime and, at the same time, to uphold a democratic society.

\section{The Issues}

From the above discussion of the O'Halloran and Francis v. The United Kingdom case, I would like to focus on two issues in this paper. Firstly, the appellants argue that their refusal to sign the NIP is akin to an accused's right of silence in criminal proceedings from the moment of arrest to the court hearing or hearings. The question asked here is whether a refusal to perform a spoken utterance may be extended to a refusal to sign a document, or to write something down as requested.

\footnotetext{
${ }^{5}$ O'Halloran and Francis $v$. The United Kingdom Par. 37

${ }^{6}$ O'Halloran and Francis $v$. The United Kingdom Par. 41. It may be argued that such a presumption conflicts with the presumption of innocence, i.e. you are guilty (of speeding) unless you can prove otherwise. That seems a topic for another paper.
} 
The second issue concerns the way this case may be seen from the point of view of symbol, index and icon, especially the latter two. ${ }^{7}$ I have already mentioned above (2.) that the texts under discussion consist of symbols, i.e. words. These symbols make up different texts which in the viewpoint of the parties to the judicial conflict become indices, and then icons.

\subsection{Silence}

I have previously set up a typology of silence in social interaction, in which I distinguish three types of silence (Kurzon 2007a, 2007b, 2009):

1) conversational silence: the type of silence often observed in everyday conversation when a participant in the conversation - frequently as one member of a dyad, but also as a member of a multi-party conversation - either does not respond to something said directly to him or her (in terms of turn-taking, s/he does not take up his or her turn although selected to do so; Sachs et al. 1974), or does not participate in a multi-party interaction, although s/he is physically present (Kurzon 1998: 32).

2) textual silence: the silence of a person, and often a group of people, while reading or reciting a text in silence. An example of this type of silence is silent prayer.

3) situational silence: This is similar to textual silence, but no text is suggested or laid down. The one-minute silence (or "moment of silence") at war remembrance ceremonies would be an example of such a silence.

Which of these types of silence would fit the refusal to sign a document or to write in general? I would argue that we have in our case an example of conversational silence. In the same way that a participant does not respond to a question addressed to him or her where $\mathrm{s} / \mathrm{he}$ is selected to take up the turn, but does not do so - the person who refuses to sign the NIP is a person who is selected to respond (by signing the form) but does not do so when a question is addressed to him or her. The silent person is present in the interaction - the Notice is addressed to him or her, but as in an everyday conversation, $\mathrm{s} /$ he becomes metaphorically non-present by not responding. It should be pointed out that while in a conversation there may be a number of reasons the addressee does not respond - here we may distinguish between intentional and unintentional silence, the latter often deriving from some psychological inhibition (Kurzon 1998: 33f.) - the addressee in the case of refusing to sign an official document is acting intentionally. Hence, silence, albeit a term that relates to the world of sound and to spoken language, may be interpreted metaphorically to relate to the written and, more generally, to the visual world.

\footnotetext{
${ }^{7}$ The terms come from Peirce ( $C P$ 4.531), but I am using them as in everyday discourse, without giving a Peircian analysis of the texts and of the particular events.
} 


\subsection{Icons and indices}

As stated in the introductory paragraph to the present section, the texts under discussion consist of sets of symbols. What we will deal with here is the transformation of these sets of symbols into indices, and then the subsequent transformation of the indices into icons. As I have stated above, I am not using these terms in a strict Peircian sense (which is in any case not consistent).

The texts I am referring to here are, on the one hand, section 172 of the 1988 Act, and on the other, section 78 of PACE 1984 and the police warning concerning the right of silence read out to arrested persons. The first text is the one used by the government in their argument in favour of convicting the two appellants, and the other two texts are those used by the appellants defending their rights.

These texts are presented as indices of broader legal and social issues in the case. The 1988 Act points to the need for the modern state to set up a regulatory regime in order to control much of what is going on in the public arena. More particularly, the Notice of Intention to Prosecute (NIP), set up by section 172 of the 1988 Act, is indexical of Lord Bringham's regulatory regime. The appellants, however, look at the relevant section of PACE 1984 and the right of silence as enunciated in the police warning as indexical of human rights - of the right not to incriminate oneself. The court, according to O'Halloran and Francis' interpretation of section 78 of PACE 1984, should reject as evidence the signed NIP, since it contradicts the spirit of the police warning, especially its opening sentence: "You do not have to say anything unless you wish to do so".

The next stage in this transformation is the conversion of these indices into icons. The texts not only indicate approaches to the central issue in the case - whether in the balance between the need for a regulatory regime and civil rights, the one or the other is given more weight - but the texts are iconized. For the government, section 172 of the 1988 Act (and in other contexts, many other sections of other statutes) represents the "regulatory regime". That is, the regulatory regime is an icon representing a regime in which files, forms and reports regulate the lives of the public.

For the appellants, the two texts indicating civil rights adopt the icon of the Magna Carta, the document signed by the English King John in 1215 to prevent a more belligerent conflict between himself and the barons. This icon was suggested by the Association of British Drivers, an organization that supported and financially aided O'Halloran and Francis in their appeal to the EHR court in Strasbourg. On the website discussing this case, the Association cited Winston Churchill's A History of the English Speaking Peoples, in which he wrote:

The facts embodied in Magna Carta and the circumstances giving rise to them were buried or misunderstood. The underlying idea of the sovereignty of the law, long existent in feudal custom, was raised by it into a doctrine for the national State. And when in subsequent ages the State, swollen with its own authority, has attempted to ride roughshod over the rights or liberties of the subject it is to this doctrine that appeal has again and again been made, and never as yet, without success. (Churchill 1993; see note 2. above) 
The Magna Carta, then, is an icon of basic civil liberties and rights, which includes the right of silence. Of course, in the original charter, no mention is made of such a right. ${ }^{8}$ This specific right is in fact a latecomer to the list of rights. It may have emerged as a reaction to the proceedings of the Star Chamber, which was dissolved in the $17^{\text {th }}$ century during the conflict between the monarchy and parliament, but it was legislated upon only in 1912.

According to the Criminal Justice and Public Order Act of 1994, the police warning was changed, ${ }^{9}$ following the change of law in Northern Ireland. Section 34(1) of the 1994 Act reads:

Where, in any proceedings against a person for an offence, evidence is given that the accused-

(a) at any time before he was charged with the offence, on being questioned under caution by a constable trying to discover whether or by whom the offence had been committed, failed to mention any fact relied on in his defence in those proceedings; or

(b) on being charged with the offence or officially informed that he might be prosecuted for it, failed to mention any such fact,

being a fact which in the circumstances existing at the time the accused could reasonably have been expected to mention when so questioned, charged or informed, as the case may be, ...

a number of courts listed

may draw such inferences from the failure as appear proper. (34(2))

However, in the present case, the appellants' argument was that it was the prosecutor's task to prove that they were the drivers of the respective cars which were photographed speeding, and not to use as evidence self-incriminating notices forced upon the carowners, since they were in a no-win situation. If a car is photographed allegedly for speeding or some other traffic violation (e.g. going through a red light), and the car owner signs the $\mathrm{NIP}^{10}$, s/he incriminates him-/herself. If, on the other hand, the car owner refuses to sign, s/he violates section 1972 of the 1988 Act and is liable to be fined up to the sum laid down for the original traffic offence, and to be given penalty points. For example, for a particular driving violation, the car driver may be fined, say $£ 250$ and be given four penalty points. If s/he refuses to comply with the NIP, s/he may be fined $£ 250$ (or maybe more) and given penalty points. There is no way out. Whatever choice one makes, a similar punishment may be given.

\footnotetext{
${ }^{8}$ The closest may be Paragraph 40 of the Magna Carta, which seems to refer generally to due process.

${ }^{9}$ See 2.2. above. The present warning in England and Wales reads:

"You do not have to say anything but it may harm your defence if you do not mention, when questioned, something which you later rely on in court. Anything you do say may be given in evidence."

${ }^{10}$ O'Halloran had signed the NIP initially, but retracted.
} 


\section{The judgment}

Four separate opinions were published. The first was the majority report (of 15 judges), the second was a concurring opinion of Judge Borrego; and there were two dissident opinions, one - to be discussed below - by Judge Pavlovschi and the second by Judge Myjer. The majority supported the UK government's contention that in order to run a country, a regulatory regime was necessary. In their words:

Those who choose to keep and drive motor cars can be taken to have accepted certain responsibilities and obligations as part of the regulatory regime relating to motor vehicles, and in the legal framework of the United Kingdom, these responsibilities include the obligation, in the event of suspected commission of road traffic offences, to inform the authorities of the identity of the driver on that occasion. ${ }^{11}$

As to the right of silence of the appellants, argued to support both O'Halloran's request to retract his signature from the NIP he had originally signed and Francis' refusal to sign the document, the Court said of Francis' refusal:

The question of the use of the statements in criminal proceedings did not arise, as his refusal to make a statement was not used as evidence: it constituted the offence itself. (ibid. Par. 61)

Hence, O'Halloran and Francis lost their case.

But let us take a look at one of the two dissenting opinions, that of Judge Pavlovschi. He saw the right of silence as an icon of human rights. "Nowadays," he wrote

the prohibition of compulsory self-incrimination has become a generally recognised standard in the field of criminal procedure. (ibid. p. 22)

He viewed the icon of the regulatory regime - in this case, section 172 of the 1988 Act as

a deviation from the principle of prohibition of "compulsory self-incrimination" and a breach of the right to silence, and can be considered as subjecting the individuals concerned to a legal compulsion to give evidence against themselves. Moreover, the applicants in this case were actually subjected to legal compulsion to give evidence which incriminated them. (ibid. p. 28)

\section{Moreover, it}

is perfectly obvious that for an individual to state that he was the driver of a car which was speeding illegally is tantamount to a confession that he was in breach of the speed regulations. (ibid. p. 29)

In further support of his contention he cited not the UK police warning, but the far more severe - as far as the responsibilities of the police and prosecution are concerned American so-called Miranda warning:

\footnotetext{
${ }^{11}$ O'Halloran and Francis v. United Kingdom, Par. 57.
} 
You have the right to remain silent. Anything you say can and will be used against you in a court of law. You have the right to have an attorney present during questioning. If you cannot afford an attorney, one will be appointed for you. (ibid. p. 23)

While the question of the right to an attorney did not enter the equation in this case, if we change "Anything you say can and will be used against you in a court of law" into "Anything you write can and will be used against you in a court of law", then we may certainly see that signing the NIP may be used against the signer in a court of law. An interpretation generally held of the following clause in the Fifth Amendment of the United States Constitution

nor shall [any person] be compelled in any criminal case to be a witness against himself ...

provides constitutional backing to the Miranda warning and the right of silence. O'Halloran "was punished for making use of his fundamental right not to incriminate himself", according to Judge Pavlovschi. He then compares the severe stand in relation to traffic offenders, a relative minor - albeit large - group of offenders, ${ }^{12}$ with criminals such as murderers:

In my view it is illogical for persons who have committed minor offences to find themselves in a less favourable situation than those who have committed acts which are truly dangerous to society. (ibid. p. 31)

Although Pavlovschi, apart from citing the Miranda warning, did not relate to American law and speeding, we may add that in most states in the United States, when the car of a traffic offender is photographed a police officer would stop the offending driver after a short distance. In such a case, there is no problem with regard to the identity of the driver. It is impossible to generalize over the fifty states, but this seems to be the tendency. Moreover, police manuals do not seem to relate to the question of identity. In the Highway Safety Desk Book, published by the Advisory Committee on Highway Safety of the International Association of Chiefs of Police, ${ }^{13}$ the focus seems to be on the presence of police officers, and on the policy that fines for speeding should not be considered a means by local authorities for making money.

\section{Conclusion}

The two opposing parties in this dispute brought to the European Human Rights Court in Strasbourg adopted icons as their leading arguments to support their respective cases.

\footnotetext{
${ }^{12}$ A minor group, unless of course a serious accident occurs as a result of the infringement. In a case several years ago in Israel, a driver who was convicted of speeding, being under the influence of drink and drugs, crossing a red traffic light and killing six people, was sentenced to 16 years imprisonment.

$13 \mathrm{http} / /$ www.nhtsa.dot.gov/people/injury/enforce/deskbk.html (accessed August 2008). Information on speeding is found in Part Six: "Speed Enforcement".
} 
The UK government argued that "the regulatory regime" which obliged citizens to fill in forms, pay for licences, etc. is required to run a modern state. The appellants, O'Halloran and Francis, used basic civil rights, iconicized as the Magna Carta, as their argument that their refusal to sign a Notice of Intention to Prosecution is akin to their right of silence.

In both cases, the icon selected emerged initially as a set of symbols in specific texts. These texts then became indexical of certain argumentative positions in the legal conflict that followed. For the government, section 172 of the 1988 Road Traffic Act with supporting precedents was indexical of the regulatory regime, and for the appellants, section 78 of PACE 1984 and the police warning concerning the right of silence became the indices of their argument in favour of the right of silence. These indices were subsequently turned into icons.

The remaining matter, of course - and perhaps the more important one from a pragmatic point of view - is whether in the context of writing, not writing something is equivalent to not speaking, that is, whether "not writing" is to be considered "being silent". If so, then it may be argued the right of silence may also be applied to a refusal to sign a document. The majority of the European Human Rights Courts did not think so.

\section{References}

Churchill, Winston. 1993 (1956). A History of the English-speaking Peoples, New York: Barnes \& Noble Books.

Kurzon, Dennis. 1998. Discourse of Silence. Amsterdam: John Benjamins.

Kurzon, Dennis. 2007a. "Towards a typology of silence". Journal of Pragmatics, 39, 1673-1688. DOI: 10.1016/j.pragma.2007.07.003

Kurzon, Dennis. 2007b. "Peters Edition v. Batt: The intertextuality of silence". International Journal for the Semiotics of Law 285-303. DOI: 10.1007/s11196-007-. 9050-4

Kurzon, Dennis. 2009. "Thematic silence as metaphor". In Ken Turner and Bruce Fraser (eds.) Language in Life, and a Life in Language: Jacob Mey - A Festschrift. Emerald Group, 255-263.

Peirce, Charles. 1931-58. Collected Papers (CP) eds.Charles Hartshorne and Paul Weiss Cambridge, Mass.: Belknap Press of Harvard University Press.

Sachs, H., Schegloff, E. A., \& Jefferson, G. 1974. "A simplest systematics for the organization of turn-taking for conversation". Language, 50, 696-735. DOI: $10.2307 / 412243$ 